\title{
4. ION MICROPROBE ANALYSES OF THE SULFUR ISOTOPIC COMPOSITION OF SULFIDES IN HYDROTHERMALLY ALTERED ROCKS, DSDP/ODP HOLE 504B 1
}

\author{
Jeffrey C. $\mathrm{Alt}^{2}$ and Marc Chaussidon ${ }^{3}$
}

\begin{abstract}
An ion microprobe was used to perform in-situ measurements of the sulfur isotopic compositions of sulfide minerals in seven samples of hydrothermally altered rocks from DSDP/ODP Hole 504B. The sulfides exhibit a wide range in $\delta^{34} \mathrm{~S}$ values, from $-4.1 \%$ to $+8.3 \%$. Heterogeneities exist among different sulfide grains in a given sample as well as within individual grains. A transect across a centimeter-size pyrite crystal reveals $\delta^{34} \mathrm{~S}$ values that span the range of the entire data set, indicating a complex growth history for this crystal. The positive $\delta^{34} \mathrm{~S}$ values are similar to those reported for seafloor sulfide deposits and are interpreted to reflect a combination of sulfur leached from basalts and ${ }^{34} \mathrm{~S}$-rich sulfide derived from seawater sulfate. Incorporation of seawater-derived sulfur is greatest in a stockworklike sulfide mineralization in the core, where subsurface mixing occurred between hydrothermal fluids and seawater. Variations in $\delta^{34} \mathrm{~S}$ are attributed to (1) incorporation of variable amounts of seawater-derived sulfide, (2) kinetic effects during precipitation, (3) reservoir effects during precipitation, (4) and variations in $\mathrm{pH}$ and $\mathrm{f}_{\mathrm{O}_{2}}$.
\end{abstract}

\section{INTRODUCTION}

Our knowledge of the behavior of sulfur in submarine hydrothermal systems is based largely on experimental data and on measurements of hydrothermal vent fluids and associated sulfide deposits. The isotopic compositions of sulfide in vent fluids and sulfide deposits are interpreted to indicate that the sulfur is a combination of reduced seawater sulfate and sulfide remobilized from basalts (Arnold and Sheppard, 1981; Styrt et al., 1981; Kerridge et al., 1983; Shanks and Seyfried, 1987; Bluth and Ohmoto, 1988; Woodruff and Shanks, 1988).

In contrast to the abundant data on vent fluids and seafloor sulfide deposits, little is known about the geochemistry of sulfur in hydrothermally altered rocks from beneath the seafloor. In order to aid in understanding the behavior of sulfur during seawater interaction with the crust, in-situ isotopic analyses of sulfur from individual sulfide mineral grains in hydrothermally altered rocks from Deep Sea Drilling Project/Ocean Drilling Program (DSDP/ODP) Hole 504B were performed by ion microprobe. In contrast to conventional bulk-rock analyses that average the isotopic compositions of sulfide grains in a sample and that can be biased by the presence of sulfates (Arnold and Sheppard, 1981), analysis of individual grains as small as $50 \mu \mathrm{m}$ in diameter enables an assessment of isotopic variations on a much finer scale.

\section{Sulfur in Submarine Hydrothermal Systems}

The simplest and probably most realistic model for sulfur in submarine hydrothermal systems is a version of that proposed by Shanks et al. (1981). In this model seawater sulfate is precipitated as anhydrite when seawater penetrates the crust and is heated to temperatures of $150^{\circ}-200^{\circ} \mathrm{C}$. Because the concentration of calcium is only one-third that of sulfate in seawater, not all of the sulfate is precipitated. Although basalts can contribute additional calcium to solution, thereby decreasing the tem-

\footnotetext{
${ }^{1}$ Becker, K., Sakai, H., et al., 1989. Proc. ODP, Sci. Results, 111: College Station, TX (Ocean Drilling Program).

2 Department of Earth and Planetary Sciences, Campus Box 1169, Washington University, St. Louis, MO 63130.

3 Centre de Recherches Pétrographiques et Géochimiques, BP 20, 54501 Vandoeuvre Cedex, France.
}

perature of anhydrite deposition and increasing the amount of sulfate extracted from seawater, some sulfate probably remains in seawater when it reaches higher temperatures. At temperatures of $250^{\circ} \mathrm{C}$ or more, inorganic sulfate reduction becomes important (Shanks et al., 1981; Ohmoto and Lasaga, 1982), and sulfate is reduced through oxidation of ferrous iron in the crust or through conversion of igneous pyrrhotite to secondary pyrite (Mottl et al., 1979; Shanks and Seyfried, 1987). At the observed water/rock ratios and temperatures (around 1 and $350^{\circ} \mathrm{C}$, respectively; VonDamm et al., 1985) and at the decreased sulfate concentrations, sulfate reduction should be rapid and quantitative. Thus, no net isotopic fractionation occurs and the seawater-derived sulfide has a $\delta^{34} \mathrm{~S}$ value equal to that of seawater sulfate $\left(+21 \%\right.$; Rees et al., 1978). This ${ }^{34}$ S-rich sulfide is combined in hydrothermal solutions with variable proportions of igneous sulfur leached from basalts $(+0.1 \%$; Sakai et al., 1984) to produce the observed $\delta^{34} \mathrm{~S}$ values of sulfide in hydrothermal vent fluids and sulfide deposits $(+0.9 \%$ to $+7.4 \%$; Arnold and Sheppard, 1981; Styrt et al., 1981; Kerridge et al., 1983; Shanks and Seyfried, 1987; Bluth and Ohmoto, 1988; Woodruff and Shanks, 1988).

The preceding model can be complicated in various ways. For example, fractionation of sulfur isotopes during precipitation of anhydrite could conceivably affect the isotopic composition of residual sulfate and any sulfide derived from it. However, the $\delta^{34} \mathrm{~S}$ values of anhydrites from veins in hydrothermally altered rocks from Hole 504B are very close to that of seawater (six samples average $+21.4 \% 0 \pm 0.3 \%$; Alt et al., 1985 , this volume), suggesting only a very small fractionation. Assuming a fractionation of $0.5 \%$ during precipitation of anhydrite, Rayleigh fractionation associated with precipitation of $90 \%$ of seawater sulfate would lower the $\delta^{34} \mathrm{~S}$ of residual sulfate in solution by only $2.3 \%$. Thus, isotopic fractionation during precipitation of anhydrite does not significantly affect the sulfur isotopic composition of residual sulfate in solution.

In another scenario, rapid heating of seawater to $250^{\circ} \mathrm{C}$ and reduction of sulfate prior to anhydrite precipitation would allow a significantly greater contribution of seawater sulfur to hydrothermal fluids. Isotopic fractionation during sulfate reduction would leave residual sulfate enriched in ${ }^{34} \mathrm{~S}$, and any anhydrite subsequently precipitated would have high $\delta^{34} \mathrm{~S}$ values. However, the close similarity of the $\delta^{34} \mathrm{~S}$ values of anhydrite from Hole 504B to that of seawater sulfate indicates that sulfate reduction prior to anhydrite precipitation was negligible. 
Another important consideration is whether sulfate reduction is sufficiently rapid to be considered a batch process. At a temperature of $300^{\circ} \mathrm{C}$, the equilibrium sulfur isotopic fractionation between sulfide and sulfate in solution is $21.9 \%$ (Ohmoto and Rye, 1979). The sulfide initially produced by reduction of seawater sulfate would have a $\delta^{34} \mathrm{~S}$ around $0 \%$, essentially indistinguishable from basaltic sulfur $(+0.1 \%)$. Depending upon the temperature at which sulfate reduction occurs and the proportion of sulfate reduced, the seawater-derived sulfide component could have a $\delta^{34} \mathrm{~S}$ value anywhere from near $0 \%$ to $+21 \%$. Thus, sulfide in the vent fluids and sulfide deposits could conceivably be explained by a seawater sulfur source only, with no contribution from basaltic sulfide. The seafloor vent fluids contain $\mathrm{H}_{2} \mathrm{~S}$ but no sulfate (VonDamm et al., 1985; Bowers et al., 1988), requiring that if partial reduction of seawater sulfate occurs the residual sulfate in solution must eventually be reduced to sulfide or precipitated as anhydrite. The sulfate remaining in solution after partial reduction would be enriched in ${ }^{34} \mathrm{~S}$ : reduction of this fractionated sulfate should produce sulfide with $\delta^{34} \mathrm{~S}$ values greater than the vent fluids, and anhydrite precipitated from this residual sulfate would have $\delta^{34} \mathrm{~S}$ values greater than seawater.

Measurement of the sulfur isotopic compositions of individual sulfide grains with the ion probe can provide new information on heterogeneities in the rocks, with the potential for insight into the geochemistry of sulfur in submarine hydrothermal systems. If seawater-derived sulfide is homogeneously combined with basaltic sulfur and incorporated into the rock, relatively uniform isotopic values for sulfide grains within a given sample might be expected. Alternatively, seawater-derived sulfide may not be combined with basaltic sulfide: this could produce a bimodal isotopic population of sulfides with both basaltic and seawater compositions. If sulfate reduction is progressive, rather than a batch process, a spectrum of sulfide $\delta^{34} \mathrm{~S}$ values ranging from basaltic up to seawater or even higher values might be expected. These variations would not be detectable in bulk-rock analyses. Large sulfide crystals in veins may record fluctuations in isotopic composition of sulfide in solution during their growth. Variations within individual grains and among grains in a single sample could also indicate variations in temperature, $\mathrm{pH}$, or fugacities of oxygen and sulfur (Ohmoto and Rye, 1979).

\section{METHODS}

Sulfur isotopic compositions of sulfide grains, ranging in size from $50 \mu \mathrm{m}$ up to $1 \mathrm{~cm}$ in diameter, from seven samples of hydrothermally altered rocks from Hole 504B were determined (Fig. 1) using a modified CAMECA IMS 3F ion microprobe (Deloule et al., 1986) at the Centre de Recherches Pétrographiques et Géochimiques in Vandoeuvre, France. Rock chips were mounted in epoxy, polished, and coated with gold. A negative primary oxygen beam, $10 \mu \mathrm{m}$ in diameter, was rastered over the sample with an analyzed area of $60 \mu \mathrm{m}$ in diameter. A secondary positive beam was used without energy filtering. The instrumental mass fractionation (the difference between $\delta^{34} S$ obtained with the ion probe and the true value) was calibrated at $-69 \%$ for both pyrite and chalcopyrite on standards of these minerals with $\delta^{34} \mathrm{~S}$ values ranging from $-25 \%$ to $+20 \%$ relative to Canyon Diablo Troilite (CDT; Chaussidon et al., 1987). Under normal conditions, reproducibility of standards is generally better than $\pm 1 \%$ and within-run statistics are about $\pm 0.7 \%$. During the several days devoted to the present study, however, reproducibility of standards was somewhat poorer $( \pm 2.6 \%)$, mainly owing to instability of the primary gun.

Electron microprobe analyses of the same pyrite grains analyzed by ion microprobe were also performed in order to examine chemical heterogeneity. Using a JEOL 733 instrument, operating conditions were the following: $20 \mathrm{kV}$ accelerating voltage, $30 \mathrm{nA}$ sample current, 10-30-s counting times, and a $1-\mu \mathrm{m}$ spot size. Analytical uncertainties are $\pm 0.01 \%$ for nickel and $\pm 0.02 \%$ for cobalt.

\section{RESULTS}

Ion microprobe results are given in Table 1, along with sulfur isotopic values for pyrite and monosulfide (chalcopyrite) sulfur

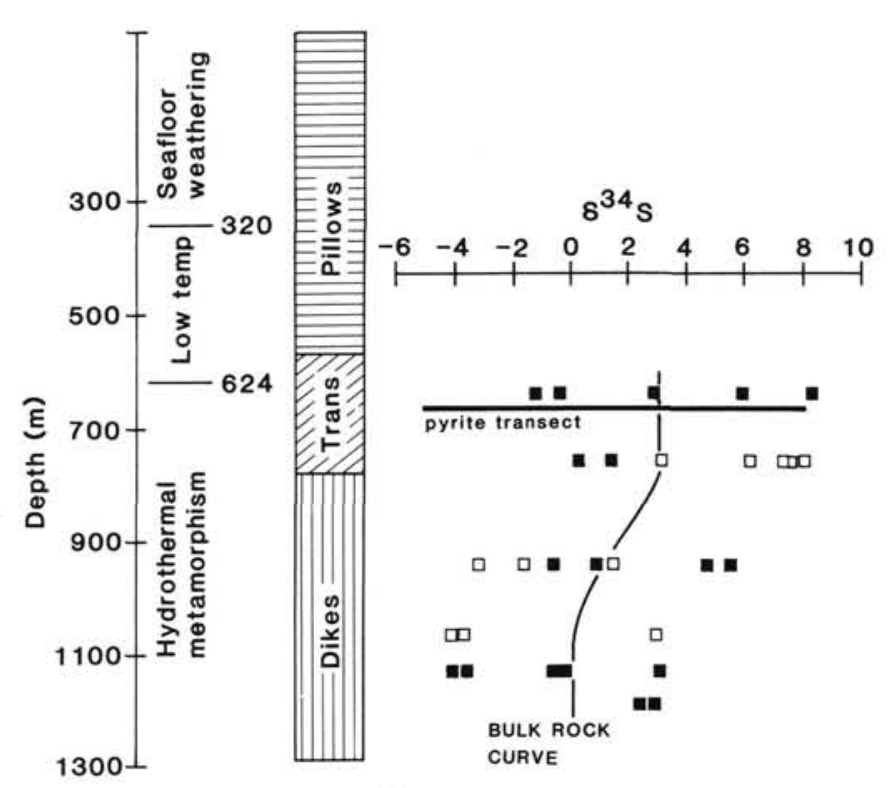

Figure 1. Ion microprobe results for Hole 504B samples. Open squares $=$ chalcopyrite; solid squares $=$ pyrite; heavy horizontal line indicates range of values for transect across a single pyrite crystal; $\delta^{34} \mathrm{~S}$ in $\%$ CDT; average bulk-rock curve based on 64 bulk-rock analyses from Alt et al. (1987, unpubl. data). Schematic lithostratigraphy and distribution of alteration zones with sub-basement depth in Hole 504B are from Alt et al. (1986).

extracted from bulk rocks (Alt et al., this volume, 1987). Within analytical uncertainty $( \pm 2.6 \%$ ), two samples (504B-94-1, 132$135 \mathrm{~cm}$, and 111-504B-155R-1, 33-36 cm) contain isotopically homogeneous pyrite. The isotopic compositions of individual grains are indistinguishable from the bulk pyrite sulfur. Chalcopyrite in these two samples is also isotopically homogeneous and similar to whole-rock chalcopyrite sulfur. In Sample 504B$94-1,132-135 \mathrm{~cm}$, chalcopyrite has higher $\delta^{34} \mathrm{~S}$ values than coexisting pyrite, whereas in another sample (504B-122-1, 88-95 $\mathrm{cm}$ ) the chalcopyrite values tend to be less than that of pyrite (Fig. 1). Pyrite and chalcopyrite in Sample 504B-94-1, 132-135 $\mathrm{cm}$, are not in isotopic equilibrium because pyrite is always enriched in ${ }^{34} \mathrm{~S}$ relative to chalcopyrite at equilibrium (Ohmoto and Rye, 1979). Disequilibrium is a common feature in seafloor sulfide deposits and in volcanogenic massive sulfide deposits in general (Franklin et al., 1981; Kerridge et al., 1983; Shanks and Seyfried, 1987; Woodruff and Shanks, 1988; Bluth and Ohmoto, 1988).

Significant isotopic variations occur among different pyrite grains within individual samples (504B-80-1, 34-38 cm, and 111-504B-147R-2, 6-10 cm). Bulk-pyrite sulfur from these samples has $\delta^{34} \mathrm{~S}$ values that fall approximately in the middle of the range of values for individual grains (Fig. 1). Significant variations in the isotopic composition of chalcopyrite occur in Sample 504B-139-1, 41-46 cm, with bulk-chalcopyrite sulfur having an intermediate $\delta^{34} \mathrm{~S}$ value.

Because the ion probe actually removes material from the grain surface during analysis, new analyses after repolishing represent different parts of individual sulfide grains. The variations in $\delta^{34} \mathrm{~S}$ of such repeat analyses of small grains may be due to heterogeneities in the grains, but the variations are within the analytical uncertainty (Table 1). In one sample (504B-80-4, 21$24 \mathrm{~cm}$ ) a traverse across a centimeter-size pyrite grain was made, with analyses spaced $200 \mu \mathrm{m}$ apart (Fig. 2). Significant isotopic variations occur within the grain. Standards were reproducible within $\pm 1 \%$ on the day this transect was performed, so the smaller variations $(2 \%)$ are significant. This transect illustrates 
Table 1. Ion microprobe results, Hole 504B.

\begin{tabular}{|c|c|c|c|c|c|c|c|}
\hline \multirow{3}{*}{$\begin{array}{l}\text { Core, section, } \\
\text { interval }(\mathrm{cm})\end{array}$} & \multirow{3}{*}{$\begin{array}{l}\text { Depth } \\
\text { (mbsf) }\end{array}$} & \multirow[b]{3}{*}{ Mineral } & \multicolumn{3}{|c|}{$\left(\%_{00}^{\delta^{34} \mathrm{CDT}}\right)$} & \multirow{3}{*}{$\begin{array}{l}\text { Nickel } \\
\text { (wt } \% \text { ) }\end{array}$} & \multirow{3}{*}{$\begin{array}{l}\text { Cobalt } \\
\text { (wt \%) }\end{array}$} \\
\hline & & & \multirow{2}{*}{$\begin{array}{l}\text { Ion } \\
\text { probe }\end{array}$} & \multicolumn{2}{|r|}{ Bulk } & & \\
\hline & & & & Pyrite & Chalcopyrite & & \\
\hline \multirow[t]{5}{*}{$80-1,34-38$} & 635.9 & Pyrite & -0.4 & 3.4 & & $0-0.30$ & $0-0.70$ \\
\hline & & Pyrite & 8.3 & & & & \\
\hline & & Pyrite-vein mineral & -1.3 & & & $0.02-0.05$ & - \\
\hline & & Pyrite & 5.9 & & & $0.72-0.97$ & 0.14 \\
\hline & & Pyrite & 2.9 & & & - & 0.04 \\
\hline \multirow[t]{14}{*}{$80-4,21-24$} & 642.5 & Pyrite-vein mineral & -0.2 & & & - & - \\
\hline & & Transect across single grain & 3.6 & & & 0.02 & - \\
\hline & & & 2.1 & & & 0.02 & - \\
\hline & & & 4.1 & & & 0.02 & - \\
\hline & & & 4.5 & & & - & - \\
\hline & & & 1.4 & & & 0.02 & - \\
\hline & & & 2.1 & & & 0.03 & - \\
\hline & & & 0.7 & & & - & 0.03 \\
\hline & & & 1.5 & & & - & - \\
\hline & & & 2.1 & & & & \\
\hline & & & -0.2 & & & & \\
\hline & & & 8.0 & & & & \\
\hline & & & 7.8 & & & & \\
\hline & & & -4.9 & & & & \\
\hline \multirow[t]{9}{*}{$94-1,132-135$} & 756.1 & Pyrite & 1.4 & 3.1 & & $0-0.12$ & $0-0.04$ \\
\hline & & Pyrite & 0.3 & & & $0-0.16$ & - \\
\hline & & Chalcopyrite-vein mineral & 7.8 & & 3.1 & & \\
\hline & & Chalcopyrite-vein mineral & 8 & & & & \\
\hline & & Chalcopyrite-vein mineral & 7.8 & & & & \\
\hline & & Chalcopyrite-vein mineral & 7.3 & & & & \\
\hline & & Chalcopyrite-vein mineral & 3.1 & & & & \\
\hline & & Chalcopyrite-vein mineral & 6.2 & & & & \\
\hline & & Chalcopyrite-vein mineral & 7.6 & & & & \\
\hline \multirow[t]{4}{*}{$122-1,88-95$} & 939.9 & Chalcopyrite-vein mineral & $-3.2,{ }^{a} 1.4$ & & & & \\
\hline & & Chalcopyrite-vein mineral & -1.7 & & & & \\
\hline & & Pyrite-vein mineral & $0.9,{ }^{a}-0.6$ & & & $0.02-0.03$ & $0-0.04$ \\
\hline & & Pyrite-vein mineral & $4.7,5.5,{ }^{a} 4.8$ & & & - & - \\
\hline \multirow[t]{3}{*}{$139-1,41-46$} & 1062.5 & Chalcopyrite & -3.7 & & 0.7 & & \\
\hline & & Chalcopyrite & -4.1 & & & & \\
\hline & & Chalcopyrite & 2.9 & & & & \\
\hline \multirow[t]{3}{*}{$147 \mathrm{R}-2,6-10$} & 1128.6 & Pyrite & $-0.6,^{a}-4.1$ & 0.4 & & $0.02-1.75$ & $0-0.05$ \\
\hline & & Pyrite & $3.1,{ }^{a}-0.3$ & & & $0.49-0.55$ & - \\
\hline & & Pyrite & -3.7 & & & $0.04-0.07$ & - \\
\hline \multirow[t]{2}{*}{$155 \mathrm{R}-1,33-36$} & 1186.6 & Pyrite & 2.9 & 0.0 & & $0-0.25$ & - \\
\hline & & Pyrite & 2.4 & & & $0.03-0.20$ & $0.03-1.7$ \\
\hline
\end{tabular}

Note: Blank entry indicates no analysis; - indicates none detected.

a Analysis after repositioning.
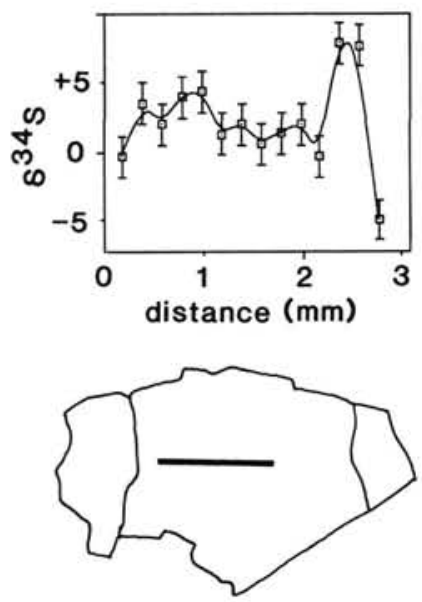

Figure 2. Ion probe transect across a single pyrite crystal (Sample 504B$80-4,21-24 \mathrm{~cm}$ ). Heavy line in bottom sketch of pyrite grain shows the location of 2.8-mm-long transect; curved subvertical lines are cracks. Values of $\delta^{34} \mathrm{~S}$ (in \% CDT) vs. distance along transect are shown at top. the importance of in-situ analyses with the ion probe. The average of the $14 \delta^{34} \mathrm{~S}$ measurements is $+2.3 \%$, very similar to the bulk $\delta^{34} \mathrm{~S}$ values for pyrite in Cores 80 and $81(+2.3 \%$ to $+4.0 \%$; Alt et al., 1987), whereas the $\delta^{34} \mathrm{~S}$ variations found within the grain from Sample 504B-80-4, 21-24 cm, cover the entire range of values found in all the samples from this study (Fig. 1).

Significant variations in $\mathrm{Ni}$ and $\mathrm{Co}$ contents are observed among different pyrite grains in a single sample, as well as within individual pyrite grains, as shown by the transect in Sample 504B-80-4, 21-24 cm (Table 1). In some cases chemical variations correlate with differences in isotopic composition (e.g., 504B-80-1, 34-38 cm, and 111-504B-147R-2, 6-10 cm), but generally no direct correlation can be made. The variation in $\mathrm{Ni}$ and Co contents shows that the grains are chemically heterogeneous, probably as a result of a complex growth history.

\section{DISCUSSION}

Alt et al. (1986) constructed a hydrothermal history for the lithologic transition and dikes at Site 504 based on mineralogy and stable isotopic evidence. Hydrothermal alteration occurred in four different stages as the crust was generated at the spreading axis and moved away from the axis with time (Fig. 3): 


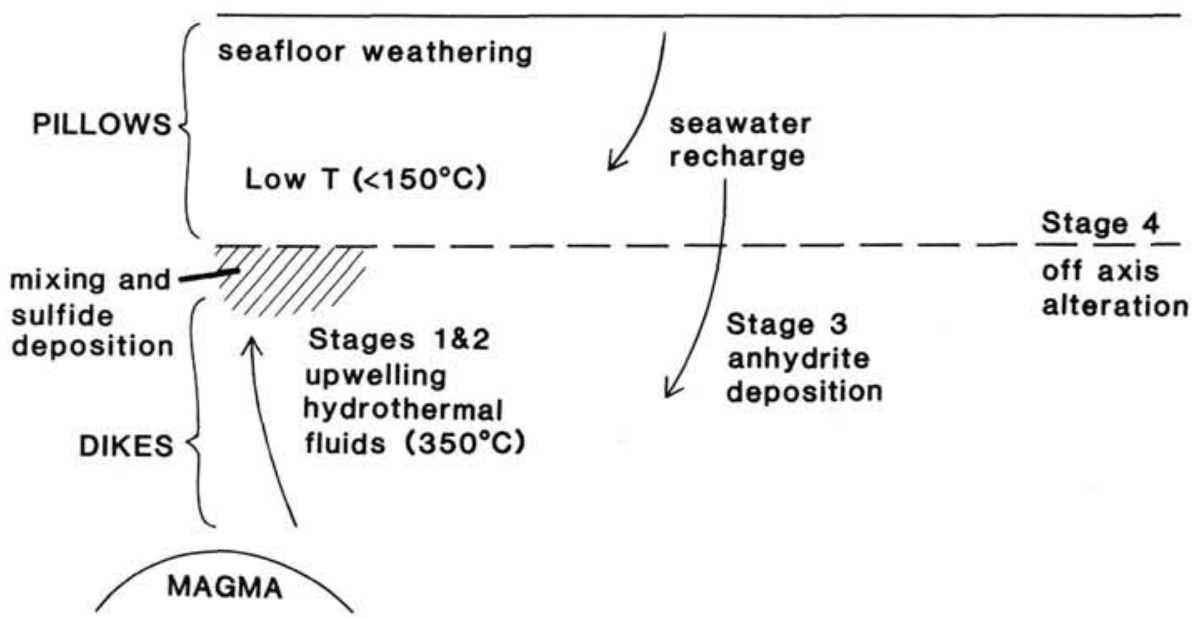

Figure 3. Diagram illustrating major alteration features and hydrothermal history at Site 504 (modified from Alt et al., 1986). As a parcel of crust moves away from the spreading axis, it passes through the various parts of a circulation cell and experiences the different alteration processes (see text). Similarly, a parcel of seawater evolves as it passes through different parts of the crust and reacts with the rock under various conditions.

1. Stage 1 axial greenschist hydrothermal alteration of the crust by seawater at temperatures of $250^{\circ}-350^{\circ} \mathrm{C}$ and water/ rock ratios around 1 .

2. Stage 2 axial upwelling of highly reacted $250^{\circ}-350^{\circ} \mathrm{C}$ hydrothermal fluids (metal enriched, $\mathrm{Mg}$ depleted) through the dikes, mixing of these fluids with cold seawater circulating in the overlying pillow section, and deposition of quartz + epidote + sulfide veins within the lithologic transition zone.

3. Stage 3 seawater recharge in the downwelling limb of a convection cell and formation of anhydrite in fractures.

4. Stage 4 off-axis alteration and formation of calcic zeolites at temperatures of $100^{\circ}-250^{\circ} \mathrm{C}$.

The sulfur isotopic compositions of sulfide minerals in Table 1 range mostly from that of fresh mid-ocean ridge basalt glass $\left(\delta^{34} \mathrm{~S}=+0.1 \% \pm 0.5 \%\right.$; Sakai et al., 1984) to higher $\delta^{34} \mathrm{~S}$ values, up to $+8.3 \%$. These values are similar to those for sulfide in hydrothermal fluids and sulfide deposits sampled from the seafloor $\left(\delta^{34} \mathrm{~S}=+0.9 \%\right.$ to $+7.4 \%$; Arnold and Sheppard, 1981; Styrt et al., 1981; Kerridge et al., 1983; Shanks and Seyfried, 1987; Bluth and Ohmoto, 1988; Woodruff and Shanks, 1988). As discussed in the introduction, the absence of any sulfide minerals in Hole 504B with $\delta^{34} \mathrm{~S}$ values significantly greater than those of the vent fluids is consistent with sulfate reduction being a "batch" process, that is, any sulfate reaching sufficiently high-temperature $\left(>250^{\circ} \mathrm{C}\right)$ parts of the system is quantitatively reduced. The fact that $\delta^{34} \mathrm{~S}$ values of anhydrite in hydrothermally altered rocks from Hole 504B do not significantly differ from seawater sulfate is also consistent with this model and with anhydrite precipitation prior to sulfate reduction. Thus, the $\delta^{34} \mathrm{~S}$ values of sulfide minerals from Hole 504B are best interpreted to reflect hydrothermal sulfide that is a mixture of basaltic sulfide and reduced seawater sulfur. At the inferred temperatures and water/rock ratios $\left(250^{\circ}-350^{\circ} \mathrm{C}\right.$ and around 1 , respectively) essentially all sulfur in solution should be in the form of sulfide. This is consistent with the inferred stable sulfide mineral assemblage in the rocks (pyrite + chalcopyrite + pyrrhotite + magnetite; Alt et al., this volume). Assuming quantitative reduction of seawater sulfate, the heaviest $\delta^{34} \mathrm{~S}$ values indicate the presence of a maximum of about $40 \%$ seawaterderived sulfur.

Although it is not possible to prove what processes are responsible for the observed isotopic heterogeneities, some likely explanations are offered here. Spatial and temporal variations in the proportions of seawater- and basalt-derived sulfur probably account for much of the variation in $\delta^{34} \mathrm{~S}$ values. This is consistent with the multiple stages of alteration and possible multiple stages of sulfide mineral formation. Because the variation in isotopic fractionation between sulfide minerals and sulfide in solution is small over this temperature range $(1.5 \%$ to $1.0 \%$ from $250^{\circ}$ to $350^{\circ} \mathrm{C}$ for pyrite; Ohmoto and Rye, 1979), temperature variations are probably not significant.

Samples 504B-80-1, 34-38 cm, and 504B-80-4, 21-24 cm, are from a stockworklike sulfide mineralization that formed near the top of the lithologic transition zone during mixing of upwelling hydrothermal fluids with cooler seawater in the overlying pillow section (Fig. 3). At temperatures greater than $250^{\circ} \mathrm{C}$, $\mathrm{pH}$ and $\mathrm{f}_{\mathrm{O}_{2}}$ are strongly buffered by hydrothermal solutions during mixing with seawater (Janecky and Seyfried, 1984). Nevertheless, slight variations in these parameters close to the pyrite + pyrrhotite + magnetite equilibrium could produce small variations in $\delta^{34} \mathrm{~S}$ of sulfide minerals (a few per mil; Ohmoto, 1972). The general decrease in $\delta^{34} \mathrm{~S}$ values from the transition zone to the dikes (Fig. 1) is probably due to sulfate reduction and incorporation of additional seawater-derived sulfide during subsurface mixing in the transition zone. Seawater sulfate, either in solution or in previously precipitated sulfate minerals, was probably reduced by oxidation of ferrous iron in host basalts or in hydrothermal solutions during mixing. This would increase the seawater sulfide component and cause higher $\delta^{34} \mathrm{~S}$ values of sulfides. The rocks of the transition zone are slightly oxidized, and several red quartz + hematite veins occur in the core immediately beneath the stockworklike mineralization (Alt et al., 1986), supporting this hypothesis. In-situ reduction of seawater sulfate in the walls of sulfide chimneys and in the shallow subsurface around seafloor vents has been proposed as the cause 
of high and variable $\delta^{34} \mathrm{~S}$ values for sulfide in hydrothermal vent fluids $(+1.3 \%$ to $+7.4 \%$; Janecky and Seyfried, 1984 ; Shanks and Seyfried, 1987; Woodruff and Shanks, 1988).

The negative $\delta^{34} \mathrm{~S}$ values of sulfide minerals in Table 1 can be accounted for by different processes. Because of the slight positive fractionation of ${ }^{34} \mathrm{~S}$ between pyrite and sulfide in solution $\left(1.2 \%\right.$ at $300^{\circ} \mathrm{C}$; Ohmoto and Rye, 1979), continued precipitation of pyrite in a closed system would deplete the solution in ${ }^{34} \mathrm{~S}$ and ultimately result in the formation of isotopically light pyrite from residual sulfide in solution. This cannot be the only mechanism, however, because the $\delta^{34} \mathrm{~S}$ values measured in the pyrite crystal in Sample 504B-80-4, 21-24 cm, do not systematically decrease from the center outward. Alternatively, the large positive fractionation of ${ }^{34} \mathrm{~S}$ between sulfate and sulfide in solution $\left(21.9 \% 0\right.$ at $300^{\circ} \mathrm{C}$; Ohmoto and Rye, 1979) could produce isotopically light pyrite if sulfide in solution is oxidized during mixing of hydrothermal fluids with seawater. Such a process could have occurred in the transition zone but is unlikely deeper in the section. Another possibility is that low $\delta^{34} \mathrm{~S}$ values result from kinetic fractionation during precipitation of sulfide minerals from hydrothermal solutions. This effect could also be responsible for isotopic disequilibrium between pyrite and chalcopyrite in samples from Hole 504B (Table 1; Alt et al., 1987, unpubl. data).

\section{CONCLUSIONS}

In-situ ion microprobe analyses of sulfide minerals in hydrothermally altered rocks from Hole 504B reveal significant variations in $\delta^{34} \mathrm{~S}$, ranging from $-4.1 \%$ to $+8.3 \%$. A single pyrite crystal shows as much variation as the entire data set, recording a complex history that could be overlooked in conventional bulk analyses. Variations in $\delta^{34} \mathrm{~S}$ are attributed to (1) incorporation of variable amounts of seawater-derived sulfide, (2) kinetic effects during precipitation, (3) reservoir effects during precipitation, and (4) variations in $\mathrm{pH}$ and $\mathrm{f}_{\mathrm{O}_{2}}$.

The ion probe results, combined with previously published data for anhydrite from Hole 504B, are consistent with a multistage model for sulfur in submarine hydrothermal systems:

1. Anhydrite precipitates from seawater as it penetrates the crust and is heated.

2. Sulfate remaining in solution is reduced to sulfide and combined with sulfide leached from basalts as higher temperatures $\left(>250^{\circ} \mathrm{C}\right)$ are reached.

3. Where upwelling hydrothermal fluids mix with seawater in the subsurface, additional seawater sulfate is reduced, causing higher $\delta^{34} \mathrm{~S}$ values of sulfide in the mixing zone.

\section{ACKNOWLEDGMENTS}

The authors thank reviewers J. Kerridge and H. Hubberten for comments that helped to significantly improve the paper. Comments by J. Luhr and L. Walter are also appreciated. JCA gratefully acknowledges the hospitality of Francis Albarede during his visit to the CRPG. This work was supported by a grant from JOI-USSAC and by NSF OCE8608886 .

\section{REFERENCES}

Alt, J. C., Anderson, T. F., and Bonnell, L., 1987. The mobility of sulfur during hydrothermal alteration of the oceanic crust. EOS, Trans. Am. Geophys. Union, 68:1546. (Abstract)

Alt, J. C., Honnorez, J., Laverne, C., and Emmermann, R., 1986. Hydrothermal alteration of a $1 \mathrm{~km}$ section through the upper oceanic crust, DSDP Hole 504B: mineralogy, chemistry and evolution of seawater-basalt interactions. J. Geophys. Res., 91:10309-10335.

Alt, J. C., Saltzman, E. S., and Price, D., 1985. Anhydrite in hydrothermally altered basalts: DSDP Hole 504B. In Anderson, R. N., Honno- rez, J., Becker, K., et al., Init. Repts. DSDP, 83: Washington (U.S. Govt. Printing Office), 283-288.

Arnold, M., and Sheppard, S.M.F., 1981. East Pacific Rise at latitude $21^{\circ} \mathrm{N}$ : isotopic composition and origin of the hydrothermal sulphur. Earth Planet. Sci. Lett., 56:148-156.

Bluth, G., and Ohmoto, H., 1988. Sulfur isotope study of sulfide-sulfate chimneys on the East Pacific Rise, $11^{\circ}$ and $13^{\circ} \mathrm{N}$ latitudes. Can. Mineral., 26:505-516.

Bowers, T. S., Campbell, A. C., Spivack, A., and Edmond, J. M., 1988. Chemical controls on the composition of vent fluids at $13^{\circ}-$ $11^{\circ} \mathrm{N}$ and $21^{\circ} \mathrm{N}$, East Pacific Rise. J. Geophys. Res., 93:4522-4536.

Chaussidon, M., Albarede, F., and Sheppard, S.M.F., 1987. Sulphur isotope heterogeneity in the mantle from ion microprobe measurements of sulphide inclusions in diamonds. Nature, 330:242-244.

Deloule, E., Allègre, C., and Doe, B., 1986. Lead and sulfur isotope microstratigraphy in galena crystals from Mississippi-valley type deposits. Econ. Geol., 81:1307-1321.

Franklin, J. M., Sangster, D. M., and Lydon, J. W., 1981. Volcanic-associated massive sulfide deposits. In Skinner, B. J. (Ed.), Economic Geology 75th Anniversary Volume: El Paso (Economic Geology), 485-627.

Janecky, D. R., and Seyfried, W. E., 1984. Formation of massive sulfide deposits on ridge crests: incremental reaction models for mixing between hydrothermal solutions and seawater. Geochim. Cosmochim. Acta, 48:2723-2738.

Kerridge, J. F., Haymon, R. M., and Kastner, M., 1983. Sulfur isotope systematics at the $21^{\circ} \mathrm{N}$ site, East Pacific Rise. Earth Planet. Sci. Lett., 66:91-100.

Mottl, M. J., Holland, H. D., and Corr, R. F., 1979. Chemical exchange during hydrothermal alteration of basalt by seawater, II. Experimental results for Fe, Mn, and sulfur species. Geochim. Cosmochim. Acta, 45:869-884.

Ohmoto, H., 1972. Systematics of sulfur and carbon isotopes in hydrothermal ore deposits. Econ. Geol., 67:551-578.

Ohmoto, H., and Lasaga, A. C., 1982. Kinetics of reactions between aqueous sulfates and sulfides in hydrothermal systems. Geochim. Cosmochim. Acta, 46:1727-1745.

Ohmoto, H., and Rye, R. O., 1979. Isotopes of sulfur and carbon. In Barnes, H. L. (Ed.), Geochemistry of Hydrothermal Ore Deposits: New York (Wiley), 509-567.

Rees, C. E., Jenkins, W. J., and Monster, J., 1978. The sulphur isotopic composition of ocean water sulphate. Geochim. Cosmochim. Acta, 42:377-381.

Sakai, H., DesMarais, D. J., Ueda, A., and Moore, J. G., 1984. Concentrations and isotope ratios of carbon, nitrogen, and sulfur in ocean floor basalts. Geochim. Cosmochim. Acta, 48:2433-2441.

Shanks, W. C., Bischoff, J. L., and Rosenbauer, R. J., 1981. Seawater sulfate reduction and sulfur isotope fractionation in basaltic systems: interaction of seawater with fayalite and magnetite at 200$350^{\circ} \mathrm{C}$. Geochim. Cosmochim. Acta, 45:1977-1995.

Shanks, W. C., and Seyfried, W. E., 1987. Stable isotope studies of vent fluids and chimney minerals, southern Juan de Fuca Ridge: sodium metasomatism and seawater sulfate reduction. J. Geophys. Res., 92: 11387-11399.

Styrt, M. M., Brackmann, A. J., Holland, H. D., Clark, B. C., Pisutha-Arnold, V. M., Eldridge, C. S., and Ohmoto, H., 1981. The mineralogy and isotopic composition of sulfur in hydrothermal sulfide/sulfate deposits on the East Pacific Rise, $21^{\circ} \mathrm{N}$ latitude. Earth Planet. Sci. Lett., 53:382-390.

VonDamm, K. L., Edmond, J. M., Grant, B., Measures, C. I., Walden, B., and Weiss, R. F., 1985. Chemistry of submarine hydrothermal solutions at $21^{\circ} \mathrm{N}$, East Pacific Rise. Geochim. Cosmochim. Acta, 49:2197-2220.

Woodruff, L. G., and Shanks, W. C., 1988. Sulfur isotope study of chimney minerals and vent fluids from $21^{\circ} \mathrm{N}$, East Pacific Rise: hydrothermal sulfur sources and disequilibrium sulfate reduction. $J$. Geophys. Res., 93:4562-4572.

Date of initial receipt: 12 April 1988

Date of acceptance: 5 September 1988

Ms 111B-151 